Article

\title{
Time Overrun in Public Works-Evidence from North-East Italy
}

\author{
Giuliano Marella and Valentina Antoniucci * \\ ICEA, Department of Civil, Architectural and Environmental Engineering, University of Padova, via Venezia 1, \\ 35131 Padova, Italy; giuliano.marella@unipd.it \\ * Correspondence: valentina.antoniucci@unipd.it
}

Received: 15 October 2019; Accepted: 4 December 2019; Published: 10 December 2019

check for updates

\begin{abstract}
Cost and time overruns in public mega-projects have been widely studied and considered as interdependent factors in the literature on project management and the public economy. On the other hand, small-scale projects for public works (costing under $€ 100$ million) are far more common and contribute to transforming cities and territories even more than mega-projects. Is the development of these kinds of projects affected in the same way by overrun issues? Do cost and time overruns always go hand in hand? The present contribution tries to answer these questions by means of an empirical study on a dataset of 4781 small public works planned and built in the Veneto Region (north-east Italy) from 1999 to 2018. Specifically, the analysis refers to the stage of development when the decision is made to outsource the work, that is, after the project's design and before its construction. Our sample of data is considered both as a whole and clustered by period, cost, contractor and category of work. The results of our analysis and statistical modeling are counterintuitive, suggesting that time overruns do not depend on the cost dimension, whereas norms and regulations play a crucial part in extending the duration of public works. The threshold by law of 1 million $€$ costs implies time-consuming procedures to verify abnormal offers in the bid, that double the average award time from 244 days to 479 days.
\end{abstract}

Keywords: risk assessment; public investment; economic feasibility; time overrun; public works

\section{Introduction}

A large body of literature is devoted to the adequacy of cost and time assessments for major public projects, focusing specifically on the cost overrun of such projects (see, among others, References [1-3]). Nevertheless, the performance of the project and design of public works does not seem to improve, regardless of location or typology of work. The present contribution is focused on the time needed for the procedures of the awards by public authorities, which is one of the less-studied phases of the development of public work. Specifically, the aim is to verify whether the law's requirements affect the time to fulfill the awards. In times of scarce economic resources and public funds, cost and time overruns are particularly damaging to communities. Worse still, "particular groups, who are often already disadvantaged, are sometimes forced to carry a disproportionate share of negative environmental and social impacts from projects that do not even deliver the promised benefits" [1]. The purchase of works and services by public authorities guarantees the homogeneous urban and regional development of cities and territories. Inefficiencies in public procurement consequently damage individuals and communities, while an efficient delivery of public works may "hamper the full satisfaction of public needs" ([4], p. 809). The cost and time overrun of projects is a relevant issue all over the world, affecting all categories of works, from civil engineering projects like highways, dams and railways to urban landmarks such as theaters, libraries and to urban brownfield restoration works.

Public works are not just a public service to the communities and they are also one of the most relevant issues for the sustainability of the National public economy. Public procurement represents in 
the OECD's Countries the $12 \%$ of Gross Domestic Product (GDP) (while in the EU public procurement is the $14 \%$ of GDP) and the $29 \%$ of government expenditure on average, which is a total amount of 6 trillion euros per year [5]. Looking at the values and goals of the public economy, "public procurement has been included in the Sustainable Development Goals, as part of Goal 12, Responsible consumption and production" ([5], p. 4).

Much attention has been paid to mega-projects [6], such as the Channel tunnel or Sydney Opera House, because of their vast impact on the public purse and their relevance to regional development. However, the idea that high cost overruns and long delays are only associated with major projects seems to be questionable. A few studies have already described different patterns of cost and time overrun depending on the size of the projects concerned [7] but the effectiveness of public procurement and development methods for small projects has been scarcely analyzed to date. It is well known, however, that most public works are relatively small in terms of cost, physical dimension and time of execution-especially in times of severe budget constraints-in Southern European countries, at least. Hence the relevance of assessing these kinds of project too, which mostly involve the ordinary maintenance of cities and territories. According to Bruzelius et al. [8], mega-projects can be defined as works with an expected lifetime of at least 50 years and implying investments of US \$1 billion and more. The bigger the project, the more difficult it is to forecast the uncertainty and volatility of features affecting the execution of the works. This means that any discussion of large-scale works often boils down to telling the unique story of a given construction and it is very hard to obtain a homogeneous historical track record of such works.

Small-scale projects should be more straightforward and more common than mega-projects, so it should be easier to forecast the cost and time of their completion. The aim of the present contribution is to see whether accountability for small projects is actually greater than for mega-projects by focusing on time overrun issues in public project management. In our scenario, we found that delays are at least partly due to Italian legislation on public works.

Unlike the case of other building works, a public works contract has to strictly follow the various phases imposed by legislation and the structure of public procurement. This aspect has rarely been considered in the existing literature, which focuses mostly on methods for predicting the uncertainty over time in a project's management. The procedures and timing required by public authorities have become more and more relevant in Italy, where the legislation governing public works has changed more than six times in the last 25 years.

To measure the influence of legislation on time overruns for public works in Italy, we collected and analyzed a large dataset concerning public works scheduled from 1999 to 2018 in the Veneto Region (north-east Italy). The maximum investment was always under $€ 100$ million and the works ranged from small urban maintenance works to highway projects.

The goals of this paper are-(1) to provide additional original data on the magnitude of time overruns in public works projects in northern Italy; (2) to highlight any differences between the time overruns affecting small-scale projects and the more often-studied major projects; and (3) to suggest an empirical framework to explain time overruns in Italy, focusing on the role of Italian legislation.

The remainder of the article is divided as follows-Section 2 provides an overview of the literature on the topic of time overruns in public works and a brief account of Italian legislation on public works; Section 3 illustrates our dataset and descriptive statistics; Section 4 discusses our model and the results of our statistical analyses; and the Conclusion provides some suggestions for further research on the topic.

\section{Schedule Delays-An Overview from Literature to Legislation}

\subsection{Time Overrun in the Scientific Literature}

Time overruns are generally represented as being a consequence of the more important project management issue, cost overrun, which has been amply investigated in the literature on public and private works. So, cost and time overruns are seen as related in most theoretical works (see, for 
instance, References [1,2,7]) and empirical research (see, among others, References [5,8-11]), though some studies, mostly developed in emerging countries, have addressed cost and time overruns as two separate issues [12-15].

Studies on underperformance in public works can be divided into three main groups. One comprises research conducted by modeling samples of project data to predict increases in the costs and time required to complete them [16-20]. Among others, the methods most often used in such studies are-fuzzy logic "to model the relationships between the characteristics of a project and the potential risk events that may occur" ([18], p. 503); econometric analyses, such as the multistep approach [21-23], the three stages square technique [24] or the stochastic Global Cost [25], which can be used to estimate the effects of factors associated with the contract bidding process, the type of project and the design; and artificial neural networks $[26,27]$. This kind of research is not extensively discussed here because it is beyond the scope of the present work but it is worth mentioning that the most common "root causes" of rising costs and delays are the size of the project and an underestimation, in the project design and development phase, of risks relating to conditions on-site $[28,29]$. The second group of studies examines the main causes of cost and time overruns mostly taking a qualitative approach, such as structured and semi-structured interviews with the actors involved in construction industries $[12,15,30]$. This type of analysis probably accounts for the bulk of the international literature and it mainly generates a taxonomy of causes, divided into categories ranging from project design to the structure of public contracts. The third group of studies includes statistical analyses and efforts to design a theoretical framework for cost and time overruns [31-33]. A general consensus identifies the underestimation of risks and uncertainties as the core reason for rising costs and delays, especially in major and mega-projects. Flyvbjerg defines public authorities' and developers' tendency to underestimate potential problems as an "optimism bias" [27] that prevails over any "strategic misinterpretation" [2] in explaining why the costs of a project are underestimated and its benefits are overestimated. Flyvbjerg's theoretical explanation is disputed by Love [34], who shifts the focus to distortions in competitive tendering to select project design firms and building contractors-the selection process tends to compress the fee excessively and to raise unrealistic expectations regarding design aspects and the paperwork involved. van Marrewijk et al. [33] also consider the restrictions imposed by project governance as interfering with the proper management of a project's development. This focus on the role of laws and norms in project management moves away from the majority of the literature on the topic of cost and time overruns, which tends to underscore the centrality of the design and planning phase of the process.

Far fewer research articles have concentrated on time overruns, in particular and on the role of procurement in causing them. After conducting a questionnaire-based survey, Larsen et al. [10] support the conviction that delays are largely due to poor project design and planning but they also highlight the different incidence of these factors on the time to completion, cost and quality of a project. Sepasgozar et al. [35] conduct a systematic bibliographic review on time delay in construction projects and highlight the potential of the new digital tools such as BIM to reduce the delays. Assaf and Al-Hejji [30] analyze major project delays in emerging economies. A survey conducted on owners, consultants and contractors identified several factors affecting time constraints-all three parties agreed that the most important causes of time overruns were changes in government regulations and laws, job site management issues and accidents during the construction phase. They also mentioned the relevance of workforce quality and productivity. These are issues more likely to affect building works in emerging economies than in Western countries (where the literature has focused on shortcomings in planning and an underestimation of the risks in the design phase). Nevertheless, studies conducted in the Far East have also pointed to the role of contractual commitments and the need to avoid litigations between owners and contractors as crucial factors influencing the expected time to complete a development [36].

As for the Italian context, Guccio et al. [37] identify the dimension of the public government body involved as a key factor in time overruns. They report empirical research leading to the conclusion 
that projects promoted by local authorities took longer to complete than works commissioned by the country's central government. Along the same lines, when Gori et al. [4] analyzed a dataset concerning public works in Tuscany (central Italy) for local authorities, they found that "insufficient procurement experience is associated with a higher probability of incurring delays and longer work durations" (p. 822). Public works require a level of specialization that not all local authorities possess [38].

The present empirical analysis contributes to the literature on these issues, focusing on small and medium-sized projects and highlighting the role of national regulations on public works as a potential cause of delays.

\subsection{Italian Legislation on Public Works}

The so-called Code of Public Works, Services and Supply Contracts (Legislative Decree n. 50/2016) is the latest in a number of revisions of the regulations covering the awarding of public works to have been implemented in Italy over the last 50 years. The revisions were needed partly to comply with EU laws aiming to improve the "design" of contract awarding procedures and to enforce "principles of publicity, transparency and equal treatment" ([32], p. 210). Since 1999, the first year covered by our analysis, the legislation on this matter has changed significantly at least three times.

The Code essentially considers three main aspects-the phase of the works to be awarded (i.e., design, construction, and/or works management); the procedure for selecting the contractor; and the selection criteria. The Italian regulations envisage two types of agreement-the procurement contract; and the concession contract. The former relates to the construction phase or, rarely, to the executive project design and the construction. The latter covers construction and works management. The competition procedures covered by the Code are the most important aspects of the process for our purposes here because they can play a remarkable part in explaining delays in the completion of the works. There are four types of tender:

1. open procedures;

2. restricted procedures;

3. restricted procedures with negotiation;

4. negotiation without a call for tenders.

The first, open procedure is one of the most often used. There is a call for tenders containing a detailed description of the object of the contract and the characteristics required of potential bidders. Fulfillment of all the requirements is only ascertained when the bids are examined. The restricted procedure is used for works costing less than $€ 1.5$ million. It involves an initial prequalification phase to ascertain what requisites a contractor will need and then identify at least five enterprises to invite on the basis of their expertise and technical endowment. Then only selected enterprises are invited to a second bidding phase. In the third type of procedure, invited enterprises make a bid on the grounds of which negotiation is conducted to improve the proposal both technically and economically.

As Decarolis and Giorgiantonio explained [39], in Italy there is not much difference between open and restricted procedures because all applicants fulfilling the requirements must be invited to make a bid when the value of the work is less than $€ 40$ million.

The last procedure applies to a very limited number of cases, mostly in emergencies or in cases where only one enterprise is capable of doing the work. The public administration asks the enterprise in question to make a bid for the work and then negotiates with them to improve on their proposal.

In the case of public-private partnerships (PPP), for project financing, for instance, the awarding of the contract is divided into two phases and the second phase involves a restricted procedure with negotiation.

There are basically two criteria for assigning the works—-the "lowest price" and the "economically most advantageous offer." Clearly, the former only considers the lowest price of the works. The latter takes into account a set of other aspects of the bids as well as the price, such as the quality of the urban and project design, the duration of the building works, energy cost savings and lower maintenance 
costs. The selection is based on a scoring rule. In both cases, administrations must check for abnormal tenders or abnormally low offers. Checking for excessively low offers is a long and complicated process that varies depending on the type of bidding procedure used. The contracting authority has to set a threshold for the abnormal offer and ask the bidder for clarification. The bidder can dispute the authority's observations. Abnormal offers must be examined for works costing more than $€ 1$ million, while for works costing less abnormal offers may be excluded automatically. This screening of bids may give rise to delays that are impossible to account for in the design or construction phases but the building work may be postponed depending on the duration of the contractor selection process.

It is worth mentioning that, for PPPs, the documentation needed to present a bid includes a demonstration of the value for money (VfM) of the proposed works. We do not discuss the question of VfM here because it is beyond the scope of the present contribution.

\section{Public Works in Italy and the Veneto Region-Sample Data and Descriptive Statistics}

The present analysis considers the time elapsing between the conclusion of a project's design phase and the beginning of the works, that is, all the time it takes to complete the contract awarding procedure.

This enables us to isolate the phase in the timeline that is most affected by the norms and regulations governing the contract awarding process. Project design may be affected by technical and managerial issues, while the construction phase may come up against various problems, from design errors to a workforce's low productivity or lack of specialization.

We collected an original database from the Italian State's General Accounting Department covering 19,117 public works, planned and implemented between 1999 and 2018 in the Veneto Region in north-east Italy. As in similar Italian analyses [40], we chose to include unfinished works too. Otherwise, the sample could be biased by an over-representation of the more efficient (or smaller and/or more straightforward) projects. The database includes the following information:

- description of the work;

- location;

- category of works (e.g., infrastructure, soil protection, school and university buildings and so on);

- type of works (maintenance, restoration, renovation, new build and so on);

- $\quad$ state of progress (e.g., ongoing, completed);

- $\quad$ contractor (State, Region, municipality);

- estimated and actual dates of starting and completing each project design phase;

- estimated and actual dates of starting and completing construction;

- estimated and actual date of starting operation;

- estimated and actual costs.

The database is part of the Open Data on Italian public economy and finance collected by the State's General Accounting Department. Data on the single works are provided by the work's managers of each public contractor. So, often data are entered incomplete. We excluded projects for which we had incomplete data concerning the costs and each phase of the timeline, thus reducing the sample to 4781 public works. As shown in Figure 1 and Table 1, 55\% of the sample (i.e., 2625 projects) are extraordinary maintenance works, while new builds account for only $22 \%$ (1047 projects). Renovations of existing buildings involving a change of use amount to less than $9 \%$ and restoration work on historical buildings about $6.6 \%$. 
Table 1. Proportions of different types of project.

\begin{tabular}{ccc}
\hline Type of Project & Number of Projects & Relative Frequency (\%) \\
\hline Building extensions & 194 & 4.08 \\
Demolitions & 11 & 0.23 \\
Equipment and technology & 6 & 0.13 \\
improvement & 2.625 & 54.90 \\
Extraordinary maintenance & 1.047 & 21.90 \\
New builds & 155 & 3.24 \\
Other & 425 & 8.91 \\
Renovation with a change of use & 316 & 6.61 \\
Restoration &
\end{tabular}

As shown in Table 2, the incomplete data we excluded from the sample has substantially the same proportion of the selected sample for the attribute "Type of project," with the clear predominance of extraordinary maintenance and new builds among other.

Table 2. Proportions of different types of projects of the incomplete and excluded data.

\begin{tabular}{ccc}
\hline Type of Project & Number of Projects & Relative Frequency (\%) \\
\hline Building extensions & 688 & 4.80 \\
Demolitions & 36 & 0.25 \\
Equipment and technology & 29 & 0.20 \\
improvement & 7.268 & 50.70 \\
Extraordinary maintenance & 3.441 & 24.00 \\
New builds & 738 & 5.15 \\
Other & 1.085 & 7.57 \\
Renovation with a change of use & 1.051 & 7.33 \\
Restoration &
\end{tabular}

We identified 33 categories of works (see Table 3 and Figure 2) but seven of them accounted for more than $70 \%$ of the sample. Road infrastructure is the largest category with 1365 works, followed by school buildings and buildings for social activities. Social infrastructure (urban and neighborhood theaters, libraries and cultural centers) make up $11.15 \%$ of the sample. These proportions are consistent with the trend for public works in northern Italy. Countrywide, the availability of public infrastructure varies enormously between north and south [41-43], so drawing comparisons on the whole of Italy would be misleading. 
Table 3. Proportions of categories of works.

\begin{tabular}{|c|c|c|}
\hline Category of Works & Number of Projects & Relative Frequency $(\%)$ \\
\hline Agriculture and agro-industrial works, industrial plants & 4 & 0.10 \\
\hline Brownfield restoration & 14 & 0.30 \\
\hline Courts and penitentiaries & 11 & 0.20 \\
\hline Cultural heritage & 247 & 5.17 \\
\hline Defense department buildings & 11 & 0.20 \\
\hline Energy distribution & 66 & 1.38 \\
\hline Energy production & 38 & 0.80 \\
\hline Equipment and facilities for retail and service sectors & 12 & 0.30 \\
\hline Fishing facilities & 1 & 0.00 \\
\hline Public health buildings and facilities & 79 & 1.65 \\
\hline Housing & 298 & 6.23 \\
\hline ICT infrastructure & 8 & 0.20 \\
\hline Infrastructure-airport & 1 & 0.00 \\
\hline Infrastructure and facilities for industrial areas & 17 & 0.40 \\
\hline Multimodal transportation & 6 & 0.10 \\
\hline Offices and administrative buildings & 122 & 2.55 \\
\hline Protection, improvement and use of the environment & 120 & 2.51 \\
\hline Public security infrastructure & 13 & 0.30 \\
\hline R\&D works and infrastructure & 5 & 0.10 \\
\hline University R\&D projects & 1 & 0.00 \\
\hline Railways & 16 & 0.30 \\
\hline Religious sites & 20 & 0.40 \\
\hline Road infrastructures & 1365 & 28.55 \\
\hline Schools and buildings for social activities & 896 & 18.74 \\
\hline Social infrastructures & 533 & 11.15 \\
\hline Soil protection & 322 & 6.73 \\
\hline Sport, entertainment and free time activities & 339 & 7.09 \\
\hline Telecommunications infrastructures & 13 & 0.30 \\
\hline Tourist facilities & 2 & 0.00 \\
\hline Urban transportation & 10 & 0.20 \\
\hline Waste management & 47 & 0.10 \\
\hline Water resources and waste water & 111 & 2.32 \\
\hline
\end{tabular}

As for the previous feature, the category of works also has the same structure in the selected and the incomplete, excluded data (see Table 4). The latter also has the same seven prevalent categories, with mostly the same proportion of the selected data. 
Table 4. Proportions of categories of works of the incomplete and excluded data.

\begin{tabular}{|c|c|c|}
\hline Category of Works & Number of Projects & Relative Frequency (\%) \\
\hline Agriculture and agro-industrial works, industrial plants & 23 & 0.16 \\
\hline Brownfield restoration & 53 & 0.37 \\
\hline Courts and penitentiaries & 52 & 0.36 \\
\hline Cultural heritage & 615 & 4.29 \\
\hline Defense department buildings & 315 & 2.20 \\
\hline Energy distribution & 288 & 2.01 \\
\hline Energy production & 96 & 0.67 \\
\hline Equipment and facilities for retail and service sectors & 33 & 0.23 \\
\hline Fishing facilities & 7 & 0.05 \\
\hline Public health buildings and facilities & 315 & 2.20 \\
\hline Housing & 401 & 2.80 \\
\hline ICT infrastructure & 30 & 0.21 \\
\hline Infrastructure-airport & 10 & 0.07 \\
\hline Infrastructure and facilities for industrial areas & 112 & 0.78 \\
\hline Multimodal transportation & 17 & 0.12 \\
\hline Offices and administrative buildings & 648 & 4.52 \\
\hline Protection, improvement and use of the environment & 354 & 2.47 \\
\hline Public security infrastructure & 205 & 1.43 \\
\hline R\&D works and infrastructure & 42 & 0.29 \\
\hline University R\&D projects & 0 & 0.00 \\
\hline Railways & 146 & 1.00 \\
\hline Religious sites & 201 & 1.40 \\
\hline Road infrastructures & 3.676 & 25.64 \\
\hline Schools and buildings for social activities & 2.155 & 15.03 \\
\hline Social infrastructures & 1.359 & 9.48 \\
\hline Soil protection & 1.069 & 7.46 \\
\hline Sport, entertainment and free time activities & 1.005 & 7.01 \\
\hline Telecommunications infrastructures & 46 & 0.32 \\
\hline Tourist facilities & 20 & 0.14 \\
\hline Urban transportation & 50 & 0.35 \\
\hline Waste management & 353 & 2.46 \\
\hline Water resources and waste water & 529 & 3.69 \\
\hline
\end{tabular}

The contract awarding procedure takes 271 days on average. In other words, about nine months go by between the completion of the project design phase and the start of building work on site (Table 3). This time varies enormously, from just one day to about ten years. According to the Agency for Territorial Cohesion (Agenzia per la Coesione Territoriale) [40], the average time to assign works worth less than $€ 1$ million is about 5 months, so the Veneto Region seems to perform poorly compared with the national average, despite the public authority managing the procedure being reasonably well organized [44]. 


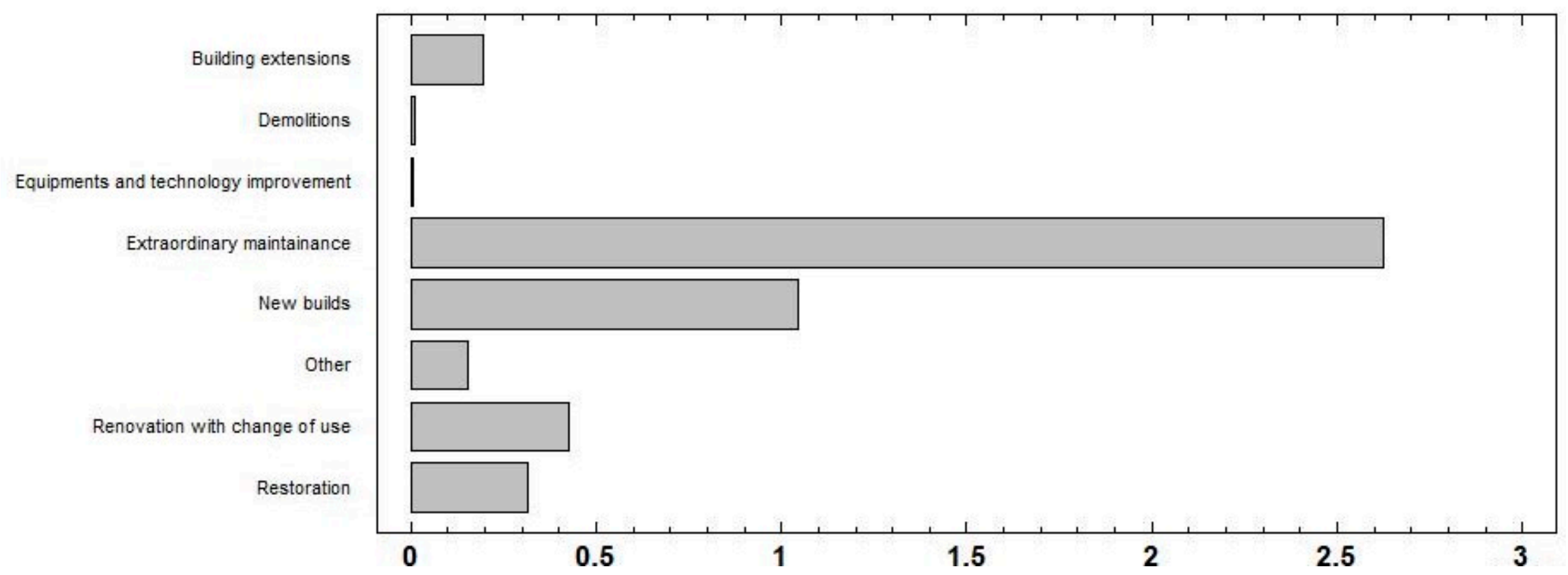

Figure 1. Proportions of types of works (frequency $1 \times 1000$ ). 


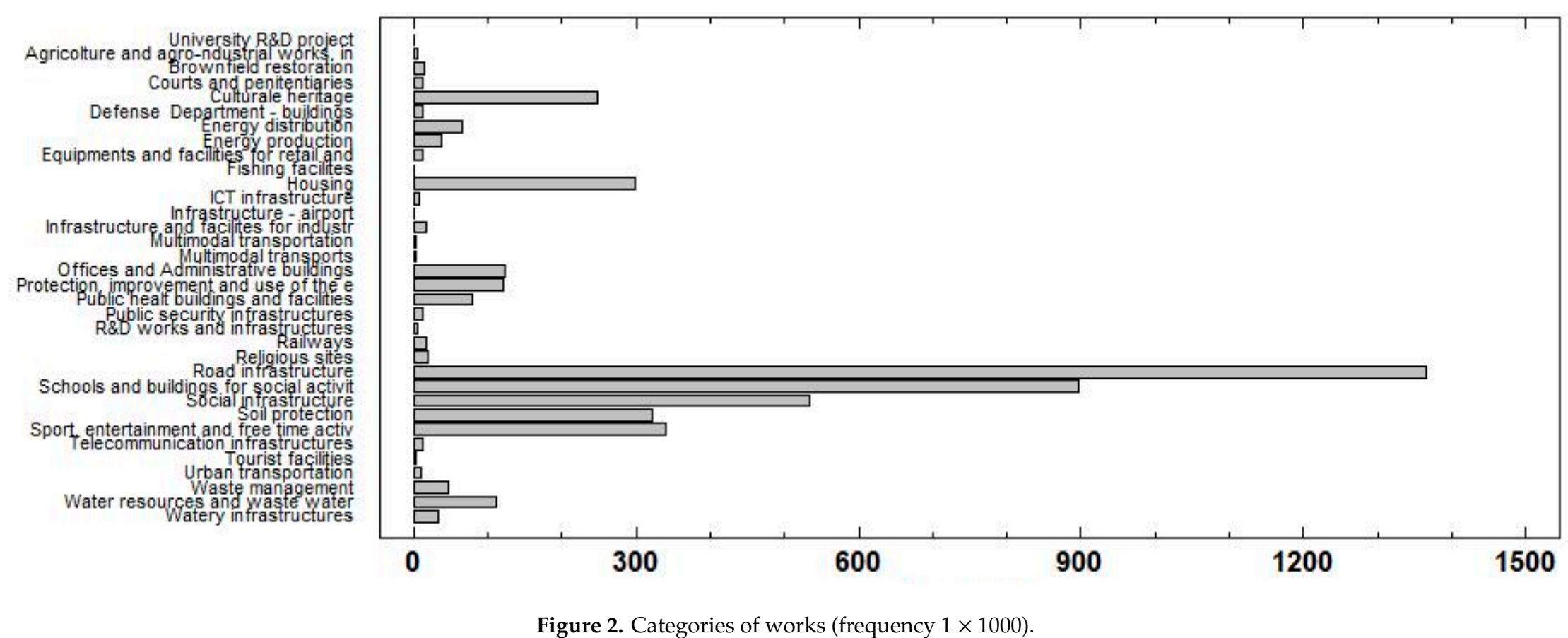

Figure 2. Categories of works (frequency $1 \times 1000$ ). 
We used "population" as a proxy of the dimension of the public authority awarding the contract, assuming that it would be more structured and specialized, the larger the population it serves $[4,37]$. This may indicate the skills available for managing the contract awarding process and consequently of the time needed to complete the procedure. As shown in Table 5, the average population is 426,650 , which is higher than that of any of the provincial capitals in the region. Although most of the contracts were awarded by local authorities ( $85.30 \%$, see Table 6), many of them (about $9 \%$ ) were promoted by territorial entities, such as Energy Service Companies (ESCOs) and utility consortia that cover larger territories than provinces. The Veneto Regional Authority and other regional bodies account for just $3 \%$ of the contracts awarded and national bodies (Ministries or the Italian Central Government) for just 9 contracts awarded in the Veneto Region during the period considered. There is marked variability in the 'local authorities' category, which reflects the different organizational capabilities of local government bodies.

Table 5. Descriptive statistics of cardinal variables.

\begin{tabular}{cccc}
\hline & $\begin{array}{c}\text { Time to Awarding } \\
\text { Contracts (Days) }\end{array}$ & Cost of Works (€) & $\begin{array}{c}\text { Population Served by the Public } \\
\text { Authority (Number) }\end{array}$ \\
\hline No. & 4783 & 4783 & 4783 \\
Mean & 271 & 651,766 & 426,650 \\
Standard deviation & 306 & $2,821,999$ & $2,615,789$ \\
Coefficient of variation & $113.00 \%$ & $432.91 \%$ & $613.02 \%$ \\
Minimum & 1.0 & 104.72 & 201.0 \\
Maximum & 3673 & $83,820,524$ & $60,589,445$ \\
\hline
\end{tabular}

Table 6. Contracts awarded by public authorities in the sample data.

\begin{tabular}{ccc}
\hline Dimension of Public Authority & Number of Awards & Incidence (\%) \\
\hline Local authorities & 4080 & 85.30 \\
Provincial authorities & 116 & 2.45 \\
Territorial authorities & 430 & 9.01 \\
Regional authorities & 146 & 3.05 \\
National authorities & 9 & 0.19 \\
Total & 4781 & 100 \\
\hline
\end{tabular}

The Threshold for Abnormal Offers—Clustering the Sample Data

Given the variability of the sample and the different requirements for awarding contracts worth more or less than $€ 1$ million, we clustered the sample into two groups based on this $€ 1$ million cutoff.

The clusters confirm that small-scale works make up most of the sample, while the projects and works costing more than $€ 1$ million accounts for just $11 \%$ (see Table 7 ).

Table 7. Descriptive statistics for clusters of contracts worth more or less than $€ 1$ million.

\begin{tabular}{ccccccc}
\hline & \multicolumn{2}{c}{ Contract Worth Less Than $€ 1$ Million } & \multicolumn{2}{c}{ CONTRACT Worth More Than $€ 1$ Million } \\
\hline & $\begin{array}{c}\text { Time to } \\
\text { Award } \\
\text { Contract } \\
\text { (Days) }\end{array}$ & $\begin{array}{c}\text { Cost of } \\
\text { Works (€) }\end{array}$ & $\begin{array}{c}\text { Population } \\
\text { Served by } \\
\text { Public } \\
\text { Authority }\end{array}$ & $\begin{array}{c}\text { Time to } \\
\text { Award } \\
\text { Contract } \\
\text { (Days) }\end{array}$ & $\begin{array}{c}\text { Cost of } \\
\text { Works (€) }\end{array}$ & $\begin{array}{c}\text { Population } \\
\text { Served by } \\
\text { Public } \\
\text { Authority }\end{array}$ \\
\hline $\begin{array}{c}\text { No. } \\
\text { Mean }\end{array}$ & 4244 & 4244 & 4244 & 537 & 537 & 537 \\
$\begin{array}{c}\text { Standard } \\
\text { deviation }\end{array}$ & 244.33 & 241,518 & 257,998 & 479.87 & $4,103,369$ & $1,755,459$ \\
$\begin{array}{c}\text { Coefficient } \\
\text { of variation } \\
\text { Minimum }\end{array}$ & $105.59 \%$ & $99.05 \%$ & $287.21 \%$ & $106.08 \%$ & $184.33 \%$ & $421.23 \%$ \\
Maximum & 1.0 & 104.72 & 201.0 & 1.0 & $1,000,000$ & 755 \\
\hline
\end{tabular}


Larger-scale works refer to a broader territory, although smaller works are also awarded on average by public bodies larger than the local authorities. The relevance of the $€ 1$ million contract value threshold emerges from the time taken to award the contracts, which is 244 days (about 8 months) for works worth less than $€ 1$ million but 480 days ( 16 months) for those worth more, that is, it takes twice as long to complete the contract awarding procedure for the latter.

Looking at the categories of works, nine categories account for more than $70 \%$ of the works in both contract value clusters but the incidence of the various categories differs significantly between the two. As shown in Table 8, "Road infrastructure" makes up 30\% of the works worth less than $€ 1$ million but only $16 \%$ of the costlier contracts. "Schools and buildings for social activities" and "social infrastructure" account for about $20 \%$ and $12 \%$ respectively of the cluster. For the works costing more than $€ 1$ million, the "Road infrastructure" and "Soil protection" are the largest categories (both making up more than 16\% of the sample), followed by "Schools and buildings for social activities" and "Housing." This latter category accounts for less than $11 \%$ of the costlier projects and just under $6 \%$ of the works costing less than $€ 1$ million. The interpretation of the different incidence of each category in the two clusters is contentious. For instance, projects relating to soil protection and water resources tend to involve a broad territory and expensive activities but we might have expected an incidence of small-scale maintenance works in the "Housing" category higher than a mere 5.7\%. Projects relating to "Social infrastructure" and "Sports, entertainment and free time activities" are usually on a neighborhood scale, so they are unsurprisingly more relevant in the cluster of projects worth less than $€ 1$ million.

Table 8. Categories of works by cluster (works costing more vs less than $€ 1$ million).

\begin{tabular}{ccc}
\hline Category of Works & \multicolumn{2}{c}{ Relative Frequency (\%) } \\
\hline Cultural heritage & $\mathbf{<} \mathbf{1}$ Million & $>\mathbf{\ell 1}$ Million \\
Housing & 4.85 & 7.64 \\
Protection, improvement and use of the environment & 5.68 & 10.61 \\
Road infrastructure & 2.43 & 3.17 \\
Schools and buildings for social activities & 30.04 & 16.76 \\
Social infrastructure & 19.56 & 11.92 \\
Soil protection & 11.88 & 4.66 \\
Sport, entertainment and free time activities & 5.54 & 16.20 \\
Water resources and waste water & 7.54 & 3.54 \\
\end{tabular}

\section{Discussion of the Statistical Analysis-The Relevance of Regulations and Norms}

We performed a simple regression to test whether the time taken to award a contract correlates with the cost of the project.

We tested this correlation on:

- the whole sample;

- the cluster of works costing less than $€ 1$ million;

- the cluster of works costing more than $€ 1$ million.

While the statistical significance of each variable is robust at $1 \%$ level, the adequacy of the model is unsatisfactory, with the $\mathrm{R}^{2}$ adj less than $10 \%$ (The $\mathrm{R}^{2}$ adj. is $1.93 \%$ for the whole sample, $4.04 \%$ for works costing less than $1 \mathrm{mil} €$ and $0.00 \%$ for works costing more than $1 \mathrm{mil} €$. Given the scarce magnitude of the $\mathrm{R}^{2}$ adj. we omitted the $p$-value for the independent variable.) This means that the variables do not contribute to explaining the phenomenon. In other words, in the sample considered here, there is not only no causal relationship but also no statistical correlation between time overruns and costs of the works. These results confirm the findings of other empirical research assessing cost and time overruns as separate issues [13-15]. We obtained the same results for the whole sample and when 
testing the model separately on the two clusters. Given the high variability of the data, we performed the same statistical analysis, clustering the sample by the contractor. We subdivided the sample into two groups-the first one contains works awarded by municipalities (n. 4080 works) and the second one, works awarded by the other public authorities (n. 701 works). Again, the results of regressions are unsatisfactory (The $\mathrm{R}^{2}$ adj. is $2.37 \%$ for the cluster with works awarded by municipalities and $1.01 \%$ for the works awarded by other public authorities. Given the scarce magnitude of the $\mathrm{R}^{2}$ adj. we omitted the $p$-value for the independent variables.).

As the dataset covers a lengthy period during which the legislation on the contract awarding procedure changed significantly three times, we divided the sample differently to check for bias relating to changes in the regulations. We considered three clusters:

- contracts awarded from 1999 to 2006;

- contracts awarded from 2006 to 2016;

- contracts awarded from 2016 to 2018.

The first cluster is the smallest, accounting for less than $1 \%$ of the sample. The second, covering the longest period makes up $76 \%$ of the whole sample and the third cluster includes $26 \%$ of the total dataset. The first cluster is too small to provide any robust statistical results while analyzing the other two clusters confirms the previous results. When we tried considering other independent variables-the cost of the works, the dimension of the public authority and the type of the works-the correlations are not strong enough to explain the time take to award the contracts The $\mathrm{R}^{2}$ adj. is $10.87 \%$ for the period 1999-2006, 3.02\% for the period 2006-2016 and 4.45\% for the period 2016-2018. Given the scarce magnitude of the $\mathrm{R}^{2}$ adj. we omitted the $p$-value for the independent variables. Given the substantial diversity of the works by type and category, we refined the sample again to test for the heterogeneity of the sample. Thus, we clustered the sample considering just the two most frequent categories of works, that are "Road infrastructures" (n. 1365 works) and "Schools and buildings for social activities" (n. 896 works) and we performed a multivariate regression for each group using cost of works and the dimension of public authority as independent variables. However, again, also in this case, the results are inadequate to demonstrate a statistical correlation between the award time and cost of works The $\mathrm{R}^{2}$ adj. is just $0.75 \%$ for the data of road infrastructures and is $5.04 \%$. Again, we omitted the $p$-value for the independent variables.

This result partly confirms the previously-mentioned literature [12-15,45] - the cost and the duration of public works, and-in the present sample - the time taken to award the contract is unrelated. The dimension of the public authority is also unrelated to the time taken to award the contract, even though the contractor's specialization is recognized as a crucial feature affecting the efficiency of the contract awarding procedure.

So what decides the amount of time it takes to award a contract? Clustering our sample of data by the abnormal offer cutoff shows that current Italian regulations on the matter, ceteris paribus, significantly influence this variable. This is also confirmed when we compared the first group of clusters (by costs) with the second ones (by time)—what does not change between the groups and represents the different regulations governing the contract awarding procedure, is the cutoff for abnormal offers (which is $€ 1$ million).

In short, the procedure needed to deal with the formalities associated with the examination of abnormal offers may double the time it takes to award a contract (244 days against 479 days for works over $€ 1$ million costs), in the sample considered here at least, as it is shown in the descriptive statistics. In fact, the procedure is time-consuming but also paves the way to litigations between bidders, that very often lead to the contract awarding procedure being suspended and/or the winner being changed by a decision of the courts. The Italian Government [40] also recognizes that the "passage time" takes up a mean $45.7 \%$ (range: $40.5 \%$ to $55.3 \%$ ) of the time needed to complete contract awarding procedures. The relevance of procedures required by law is a feature of time overrun scarcely studied. The results are underpinned by the several statistical tests performed-none of them have 
demonstrated a statistical correlation between award duration and cost, nor for the whole sample, nor for the diverse cluster tested. The findings confirm the part of the existing literature that considers time overrun unrelated with cost. This feature may not be valid for each phase of the duration of the works-during the construction phase, an increase of the costs is most of the time correlated with a time increase, due to the above-mentioned design errors and underestimation of risks, that is, in the construction site. Focusing on the procedure's duration, costs (increasing or not) may be irrelevant to the time increase, as the analysis here presented confirm. The compliance of estimated time depends on the requirements to perform the award procedures. These requirements do not change according to the kind of contractors, because they vary just for the ex-ante estimated work cost (above and below the 1 million euros threshold, as shown in Figure 3). Some public authorities, that is, small municipalities, do not have the technical expertise and the minimum staff too, to accomplish in time the procedural steps. Also, this kind of municipalities may be involved in the development of major works and/or infrastructures that they are not able to manage in time properly. Nevertheless, further and in-depth analysis is needed to extend the finding, here limited to a specific Italian Region. To generalize the result, the findings should be validated for Northern Italy at least.

\section{Conclusions}

Although there is plenty of literature on cost overruns in major and mega-projects, it does not seem to have improved the situation concerning the increase in costs and delays in completing public works. Public works are a relevant part of the National public economy and the efficiency of these investments contributes significantly to the sustainability of public accounts and finances. Moreover, the strategy adopted in public works may increase the spread of sustainable development and behavior at the local and territorial level. While there are several factors affecting the completion of public work-most of them in the design and construction phase, that is, at the beginning and end of the process-very little attention has been devoted to what happens in between. The present work considers the time taken to award contracts, which cannot be explained by considering the cost overrun (incurred largely during the construction phase, after the contract has been awarded). We provided empirical findings on the time taken to award contracts in a sample of 4781 public works projects planned and implemented from 1999 to 2018 in the Veneto Region, in north-east Italy, in an effort to find an explanation for time overruns in these procedures.

Our elaborations show that even small projects, defined here as public works costing less than $€ 100$ million, are liable to time overrun and this stems mostly from the administrative demands of laws and regulations on public works [46,47]. In particular, when we divided our sample into works using the $€ 1$ million cutoff for monitoring abnormal offers, the time taken to award public works below the cutoff is 244 days, while it almost doubles to 479 days for those above the cutoff (see Figure 3).

To check whether this difference in timeline is coincidental, we performed several statistical multivariate regressions where the time taken to award contracts is the dependent variable and the independent variables are other features conventionally assumed to affect time overruns, that is, the cost of the works, the dimension of the public authority and the category of the works. 


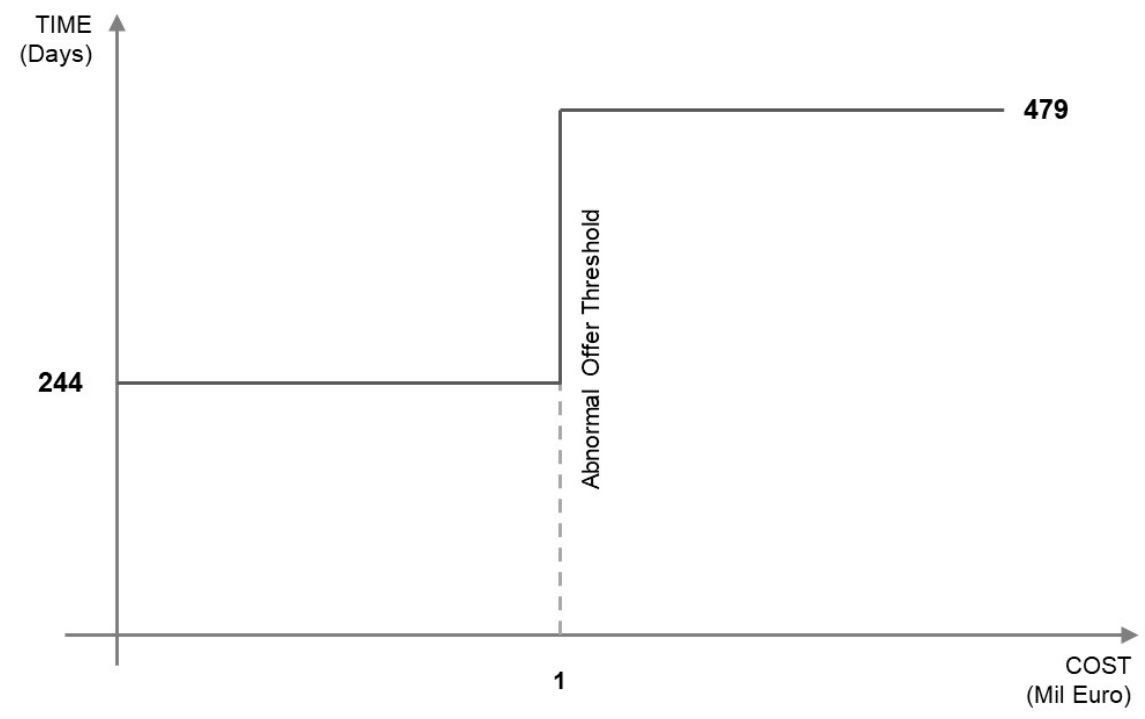

Figure 3. The effect of the abnormal offer threshold on time taken to award contracts.

We tested this model with five different specifications-in the whole sample; in two clusters by contract value (below vs. above $€ 1$ million); in two clusters by period (2006-2016 vs. 2016-2018); in two clusters by contractor (municipalities and other public authorities) and lastly testing just the two major category of works in the sample, which are "Road infrastructure" and "Schools and buildings for social activities."

All our statistical analyses demonstrate that the longer time taken to award contracts is unrelated to the cost of the works or the dimensions of the public authorities involved (as a proxy for their contract awarding expertise). This means that the extension of the time taken to award contracts can be attributed entirely to the related procedures required by law and especially to the checks on abnormal offers.

These findings point to the need for further research. To be generalizable, our findings would need to be tested on a larger sample of data and in different regions. The same set of data could also be useful for examining other phases of the public works process, such as design and construction. A further breakdown of the dataset, such as for works on historical buildings $[47,48]$ and on improvement and use of the environment [49] could help to clarify the timeline of the public works process. Lastly, the features affecting the mismatch between the expected and actual costs and times to the completion of public works are worth analyzing, also by comparison with existing literature on the topic.

Author Contributions: Conceptualization, G.M.; methodology, G.M. and V.A.; formal analysis, G.M. and V.A.; data curation, V.A.; writing-original draft preparation, V.A.; writing-review and editing, G.M. and V.A.; visualization, G. M. and V.A.; supervision, G.M.

Funding: This research was funded by the Department of Civil, Architectural and Environmental Engineering of the University of Padova, research grant number 68/2018, prot. n. 560, date 29/03/2018.

Conflicts of Interest: The authors have no potential conflict of interest to disclose concerning the research, authorship, and/or publication of this article.

\section{References}

1. Flyvbjerg, B. Over Budget, over Time, over and over again. In The Oxford Handbook of Project Management; Morris, P.W.G., Pinto, J.K., Soderlund, J., Eds.; Oxford University Press: Oxford, UK, 2011; pp. 321-344. Available online: http://ssrn.com/abstract=2278226 (accessed on 6 September 2019).

2. Flyvbjerg, B.; Holm, M.S.; Buhl, S. Underestimating costs in public works projects: Error or lie? J. Am. Plan. Assoc. 2002, 68, 279-295. [CrossRef] 
3. Flyvbjerg, B.; Ansar, A.; Budzier, A.; Buhl, S.; Cantarelli, C.; Garbuio, M.; Glenting, C.; Holm, M.S.; Lovallo, D.; Lunn, D.; et al. Five things you should know about cost overrun. Transp. Res. A Policy Pract. 2018, 118, 174-190. [CrossRef]

4. Gori, G.F.; Lattarulo, P.; Mariani, M. Understanding the procurement performance of local governments: A duration analysis of public works. Environ. Plan. C Politics Space 2017, 35, 809-827. [CrossRef]

5. OECD. Reforming Public Procurement: Progress in Implementation 2015 OECD Recommendation. 2019. Available online: https://www.oecd.org/gov/public-procurement/public-procurement-progress-reporthighlights.pdf (accessed on 23 September 2019).

6. Priemus, H.; van Wee, B. Decision-Making on Mega-Projects. In International Handbook on Mega-Projects; Edward Elgar: Cheltenham, UK; Northampton, MA, USA, 2014; pp. 9-10. [CrossRef]

7. Shrestha, P.P.; Burns, L.A.; Shields, D.R. Magnitude of Construction Cost and Schedule Overruns in Public Work Projects. J. Constr. Eng. 2013, 2013, 935978. [CrossRef]

8. Bruzelius, N.; Flyvbjerg, B.; Rothengatter, W. Big decisions, big risks. Improving accountability in mega projects. Transp. Policy 2002, 9, 143-154. [CrossRef]

9. Ullah, K.; Abdullah, A.H.; Nagapan, S.; Suhoo, S.; Khan, M.S. Theoretical framework of the causes of construction time and cost overruns. IOP Conf. Ser. Mater. Sci. Eng. 2017, 271, 012032. [CrossRef]

10. Larsen, J.K.; Shen, G.Q.; Lindhard, S.M.; Brunoe, T.D. Factors Affecting Schedule Delay, Cost Overrun, and Quality Level in Public Construction Projects. J. Manag. Eng. 2015, 32, 04015032. [CrossRef]

11. Olawale, Y.A.; Sun, M. Cost and time control of construction projects: Inhibiting factors and mitigating measures in practice. Constr. Manag. Econ. 2010, 28, 509-526. [CrossRef]

12. Kazaz, A.; Ulubeyli, S.; Tuncbilekli, N.A. Causes of Delays in Construction Projects in Turkey. J. Civ. Eng. Manag. 2012, 18, 426-435. [CrossRef]

13. Aibinu, A.A.; Odeyinka, H.A. Construction Delays and Their Causative Factors in Nigeria. J. Constr. Eng. Manag. 2006, 132, 667-677. [CrossRef]

14. Al-Kharashi, A.; Skitmore, M. Causes of delays in Saudi Arabian public sector construction projects. Constr. Manag. Econ. 2009, 27, 3-23. [CrossRef]

15. Kaming, P.F.; Olomolaiye, P.O.; Holt, G.D.; Harris, F.C. Factors influencing construction time and cost overruns on high-rise projects in Indonesia. Constr. Manag. Econ. 1997, 15, 83-94. [CrossRef]

16. Love, P.E.D.; Wang, X.; Sing, C.; Tiong, R.L.K. Determining the Probability of Project Cost Overruns. J. Constr. Eng. Manag. 2012, 139, 321-330. [CrossRef]

17. Del Giudice, V.; de Paola, P.; Francesca, T.; Nijkamp, P.J.; Shapira, A. Real Estate Investment Choices and Decision Support Systems. Sustainability 2019, 11, 3110. [CrossRef]

18. Acampa, G.; Forte, F.; De Paola, P.B.I.M. Models and Evaluations; Springer: Cham, Switzerland, 2020; pp. 351-363. [CrossRef]

19. Nesticò, A.; He, S.; de Mare, G.; Benintendi, R.; Maselli, G. The ALARP Principle in the Cost-Benefit Analysis for the Acceptability of Investment Risk. Sustainability 2018, 10, 4668. [CrossRef]

20. Knight, K.; Fayek, A.R. Use of Fuzzy Logic for Predicting Design Cost Overruns on Building Projects. J. Constr. Eng. Manag. 2002, 128, 503-512. [CrossRef]

21. Gkritza, K.; Labi, S. Estimating Cost Discrepancies in Highway Contracts: Multistep Econometric Approach. J. Constr. Eng. Manag. 2008, 134, 953-962. [CrossRef]

22. Bisello, A.; Grilli, G.; Balest, J.; Stellin, G.; Ciolli, M. Co-Benefits of Smart and Sustainable Energy District Projects: An Overview of Economic Assessment Methodologies; Springer: Cham, Switzerland, 2017; pp. 127-164. [CrossRef]

23. Antoniucci, V.; Marella, G. Immigrants and the city: The relevance of immigration on housing price gradient. Buildings 2017, 7, 91. [CrossRef]

24. Bhargava, A.; Anastasopoulos, P.C.; Labi, S.; Sinha, K.C.; Mannering, F.L. Three-Stage Least-Squares Analysis of Time and Cost Overruns in Construction Contracts. J. Constr. Eng. Manag. 2010, 136, 1207-1218. [CrossRef]

25. Fregonara, E.; Pattono, S. A sustainability indicator for building projects in presence of risk/uncertainty over time: A research experience. Aestimum 2018, 173-205. [CrossRef]

26. Boussabaine, A.H. The use of artificial neural networks in construction management: A review. Constr. Manag. Econ. 1996, 14, 427-436. [CrossRef]

27. Attalla, M.; Hegazy, T. Predicting Cost Deviation in Reconstruction Projects: Artificial Neural Networks versus Regression. J. Constr. Eng. Manag. 2003, 129, 405-411. [CrossRef] 
28. Mangialardo, A.; Micelli, E.; Saccani, F. Does sustainability affect real estate market values? Empirical evidence from the office buildings market in Milan (Italy). Sustainability 2018, 11, 12. [CrossRef]

29. Torrieri, F.; Oppio, A. The Ex-Ante Evaluation of Flood Damages for a Sustainable Risk Management; Springer: Cham, Switzerland, 2019; pp. 542-550. [CrossRef]

30. Assaf, S.A.; Al-Hejji, S. Causes of delay in large construction projects. Int. J. Proj. Manag. 2006, 24, 349-357. [CrossRef]

31. Cantarelli, C.C.; Flybjerg, B.; Molin, E.J.E.; van Wee, B. Cost overruns in Large-Scale Transportation Infrastructure Projects: Explanations and Their Theoretical Embeddedness. arXiv 2013, arXiv:1307.2176.

32. Flyvbjerg, B.; Holm, M.K.S.; Buhl, S.L. Inaccuracy in Traffic Forecasts. Transp. Rev. 2006, 26, 1-24. [CrossRef]

33. Van Marrewijk, A.; Clegg, S.R.; Pitsis, T.S.; Veenswijk, M. Managing public-private megaprojects: Paradoxes, complexity, and project design. Int. J. Proj. Manag. 2008, 26, 591-600. [CrossRef]

34. Love, P.E.D.; Edwards, D.J.; Irani, Z. Moving Beyond Optimism Bias and Strategic Misrepresentation: An Explanation for Social Infrastructure Project Cost Overruns. IEEE Trans. Eng. Manag. 2012, 59, 560-571. [CrossRef]

35. Sepasgozar, S.M.E.; Karimi, R.; Shirowzhan, S.; Mojtahedi, M.; Ebrahimzadeh, S.; McCarthy, D. Delay Causes and Emerging Digital Tools: A Novel Model of Delay Analysis, Including Integrated Project Delivery and PMBOK. Buildings 2019, 9, 191. [CrossRef]

36. Lau, C.H.; Mesthrige, J.W.; Lam, P.T.I.; Javed, A.A. The challenges of adopting new engineering contract: A Hong Kong study. Eng. Constr. Archit. Manag. 2019. [CrossRef]

37. Guccio, C.; Pignataro, G.; Rizzo, I. Do local governments do it better? Analysis of time performance in the execution of public works. Eur. J. Political Econ. 2014, 34, 237-252. [CrossRef]

38. Bencardino, M.; Nesticò, A. Spatial Correlation Analysis among Land Values, Income Levels and Population Density; Springer: Cham, Switzerland, 2019; pp. 572-581. [CrossRef]

39. Decarolis, F.; Giorgiantonio, C. Local public procurement regulations: The case of Italy. Int. Rev. Law Econ. 2015, 43, 209-226. [CrossRef]

40. Agenzia per la Coesione Territoriale, I Tempi di Attuazione delle Opere Pubbliche. 2018. Available online: http://www.agenziacoesione.gov.it/dossier_tematici/i-tempi-delle-opere-pubbliche/ (accessed on 8 November 2019).

41. Deloitte, Gli Investimenti in Infrastrutture. Relazione con la Distribuzione del Reddito e Attese di Remunerazione Finanziaria Degli Investitori. 2018. Available online: https://economiaefinanza.luiss. it/sites/economiaefinanza.luiss.it/files/180116_Report-infrastrutture_lq.pdf (accessed on 12 September 2019).

42. Forte, F.; Antoniucci, V.; de Paola, P. Immigration and the housing market: The case of Castel Volturno, in Campania Region, Italy. Sustainability 2018, 10, 343. [CrossRef]

43. Antoniucci, V.; Marella, G. Is social polarization related to urban density? Evidence from the Italian housing market. Landsc. Urban Plan. 2017, 177, 340-349. [CrossRef]

44. Canesi, R.; Marella, G. Residential construction costs: An Italian case study. Int. J. Appl. Eng. Res. 2017, 12, 2623-2634.

45. Antoniucci, V.; Marella, G. The influence of building typology on the economic feasibility of urban developments. Int. J. Appl. Eng. Res. 2017, 12, 4946-4954.

46. Prizzon, F.; Rebaudengo, M. [Unfinished Public Works: A National Heritage to Develop?] Le Opere Pubbliche Incompiute: Un Patrimonio da Valorizzare? LaborEst 2015, 11, 55-59. [CrossRef]

47. Della Spina, L.; Calabrò, F. Decision Support Model for Conservation, Reuse and Valorization of the Historic Cultural Heritage; Springer: Cham, Switzerland, 2018; pp. 3-17. [CrossRef]

48. Della Spina, L. Scenarios for a Sustainable Valorisation of Cultural Landscape as Driver of Local Development; Springer: Cham, Switzerland, 2019; pp. 113-122. [CrossRef]

49. Sturiale, L.; Scuderi, A. The Evaluation of Green Investments in Urban Areas: A Proposal of an eco-social-green Model of the City. Sustainability 2018, 10, 4541. [CrossRef]

(C) 2019 by the authors. Licensee MDPI, Basel, Switzerland. This article is an open access article distributed under the terms and conditions of the Creative Commons Attribution (CC BY) license (http://creativecommons.org/licenses/by/4.0/). 